Tijdschr Urol (2020) 10:155

https://doi.org/10.1007/s13629-020-00315-6

Q

Check for
updates

\section{Altijd op zoek naar beter}

\author{
Henk G. van der Poel
}

(C) The Author(s) 2020

Nog middenin de COVID19-epidemie blijven we zoeken naar verbetering van de urologische zorg.

In dit nummer van ons tijdschrift een samenvatting van de literatuur over HIFU als salvagebehandeling na lokale radiotherapie. Mogelijk ook door de vroegere inzet van de PSMA PET/CT-scan worden, ondanks de steeds nauwkeuriger bestralingsopties en hypofractioneringen, lokale recidieven na radiotherapie sporadisch gezien. De juiste aanpak is nog onduidelijk en het aantal opties groot. Of HIFU daarin de voorkeur heeft boven andere opties leert de literatuur nog niet. Wel zou ik voorstellen om, als het gebeurt, deze salvagebehandeling met HIFU bij voorkeur in studieverband uit te voeren.

Heel informatief is het literatuuroverzicht naar de veiligheid van testosteronsuppletie na prostaatkankerbehandeling; conclusie: geen bezwaar, zolang de normale testosteronconcentratie niet wordt overschreden.

Door een bezoek aan Rostov aan de Don kwam ik in aanraking met de bacteriofagentherapie als infectiebestrijding: mogelijk nuttig voor chronische infec- ties, maar niet voor de acute, begreep ik in Rusland. Een interessante optie bij toenemende antibioticaresistentie? In ieder geval een oplossing die nog ver verwijderd is van de richtlijnen.

Tot slot het 'nat colostoma' na totale bekken-exenteratie, een situatie waarin twee stomata meestal niet te voorkomen zijn. Er is nog weinig literatuur over, maar kortetermijnproblemen blijken beperkt en in sommige gevallen biedt het een alternatief. Gebruik van speciaal stomamateriaal lijkt me in ieder geval cruciaal en aan lekkage moet ik niet eens denken.

In ieder geval een aantal onderwerpen dat corona even doet vergeten!

Open Access This article is distributed under the terms of the Creative Commons Attribution 4.0 International License (http://creativecommons.org/licenses/by/4.0/), which permits unrestricted use, distribution, and reproduction in any medium, provided you give appropriate credit to the original author(s) and the source, provide a link to the Creative Commons license, and indicate if changes were made.

dr. Henk G. van der Poel, hoofdredacteur dr. H. G. van der Poel $(\bowtie)$

Tijdschrift voor Urologie, Bohn Stafleu van Loghum, Houten, Nederland

h.vd.poel@nki.nl 